\title{
Growth, Yield and Quality of Sweet Corn (Zea mays L. Saccharata) as Influenced by Spacing and INM Practices Under South Gujarat Condition
}

\author{
Rathod Manishaben, V. G. Bavalgave*, V. A. Patil, and S. P. Deshmukh
}

Dept. of Agronomy Navsari Agricultural University, Navsari, Gujarat (396 450), India

\section{Corresponding Author}

V. G. Bavalgave

e-mail:vgbavalgave@gmail.com

\author{
Article History \\ Article ID: IJEP0268 \\ Received in $10^{\text {th }}$ August, 2018 \\ Received in revised form $12^{\text {th }}$ October, 2018 \\ Accepted in final form $22^{\text {nd }}$ October, 2018
}

\begin{abstract}
A field experiment was conducted at college farm, N. M. College of Agriculture, Navsari Agricultural University, Navsari (GJ), during rabi season in 2016-17 to study the influence of of spacing and integrated nutrient management on sweet corn (zea mays L. saccharata) under south Gujarat condition". The experiment was laid out in Factorial randomized blok design (FRBD) with three replications. The factors consisted of three spacing $\left(45 \times 30 \mathrm{~cm}^{2}, 60 \times 20 \mathrm{~cm}^{2}\right.$ and $\left.60 \times 30 \mathrm{~cm}^{2}\right)$, three nutrient management practices (100\% RDF $(120: 60: 00 \mathrm{NPK} \mathrm{kg}$ ha-1, 75\% RDF+25\% RDN through Biocompost and 50\% RDF+50\% RDN through Biocompost) and two biofertilizers i.e. with Azotobactor+PSB+KMB and without biofertilizers. The results revealed that, spacing $60 \times 20 \mathrm{~cm}^{2}$ recorded significantly higher green cob $\left(91.93 \mathrm{q} \mathrm{ha} \mathrm{C}^{-1}\right)$ and fodder yield $\left(318.65 \mathrm{q} \mathrm{ha}^{-1}\right)$ While, Significantly higher protein content in cob $(6.97 \%)$ and fodder $(2.92 \%)$ was recorded in spacing $60 \times 30 \mathrm{~cm}^{2}\left(\mathrm{~S}_{3}\right)$. Application of $100 \%$ RDF (120:60:00 NPK kg ha $\left.{ }^{-1}\right)$ recorded the significantly highest green cob $\left(90.13 \mathrm{q} \mathrm{ha}^{-1}\right)$, fodder yield $\left(311.74 \mathrm{q} \mathrm{ha}^{-1}\right)$ and protein content in cob (6.91\%) and fodder (2.95\%). Biofertlizers i.e. Azotobacter+PSB+KMB application recorded the significantly highest green cob $\left(86.64 \mathrm{q} \mathrm{ha}^{-1}\right)$, fodder yield $\left(299.68 \mathrm{q} \mathrm{ha}^{-1}\right)$ and protein content in cob $(6.85 \%)$ and fodder $(2.85 \%)$.
\end{abstract}

Keywords: Sweet corn, Spacing, Fertilizer and Biofertilizer

\section{Introduction}

Generally, maize (Zea mays L.) is cultivated in all seasons successfully as it is classified as C4 type crop. Among the various types of maize, sweet corn is very popular for the use of its green cobs all around the world. Sweet corn is a popular vegetable and ranks second in farm value and fourth in commercial crops. Due to rising in demand, the sweet corn is able to increase the farm income.In order to achieve higher cob yields, maintenance of stand density is the most important factor. A spatial arrangement of plant governs the shape and size of the leaf area plant ${ }^{-1}$, which in turn influences efficient interception of radiant energy, proliferation, growth of roots and their activity. Maximum yield can be expected only when plant population allows individual plant to achieve their maximum inherent potential. Thus, there is need to work out an optimum population density by adjusting inter and intra row spacing in relation to other agronomic factors. India has made spectacular breakthrough in production and consumption of fertilizers during the last four decades. But consumption of renewable form of energy (chemical fertilizers) will be quite a limiting factor for increasing agriculture production in future. Because of escalating energy cost, chemical fertilizers are not available at affordable prices to the farmers. Moreover, the problem is compounded by imbalanced and indiscriminate fertilizer use, a decline in soil organic carbon due to prolonged use of chemical fertilizers. The production efficiency gone down appreciably. Thus, higher productivity on a sustained basis can be ensured only through integrated nutrient supply system including combined judicious use of chemical fertilizers, Biocompost, and biofertilizers (Yadav, 2002). Biofertilizers have an advantage over chemical fertilizers, as they provide nutrients in addition to plant growth promoting substances like hormones, vitamins, amino acids etc. (Shivankar et al., 2000). Hence, introduction of biofertilizers is necessery for improving the soil fertility and productivity becides reducing the expenditure on chemical fertilizers. The present study was, therefore, aimed to evaluvate the performance of sweet corn as influenced by spacing and integrated nutrient management.

\section{Materials and Methods}

A trial was conducted during rabi 2016-17 at College Farm, Department of Agronomy, College of Agriculture, Navsari Agricultural University, Navsari.to assess the response of rabi sweet corn (Zea mays L. var. saccharata Sturt) to spacing and integrated nutrient management under south Gujarat condition. 
The experiment comprising eighteen treatment combinations consisting three levels of plant spacing $\left(45 \times 30 \mathrm{~cm}^{2}, 60 \times 20\right.$ $\mathrm{cm}^{2}$ and $\left.60 \times 30 \mathrm{~cm}^{2}\right)$, three nutrient management practices (100\% RDF (120:60:00 NPK kg ha-1 ${ }^{-1}$ 75\% RDF+25\% RDN through Biocompost and 50\% RDF+50\% RDN through Biocompost) and two biofertilizers i.e. with Azotobactor+PSB+KMB and without biofertilizers. These treatments were replicated three times in a Factorial Randomized Block Design. Field was prepared by ploughing followed by passing the harrow and leveler. The seeds of Sweet corn (cv. Sugar 75) was sown in the present experiment.

The experimental soil was clayey and low in available $\mathrm{N}$, medium in available $\mathrm{P}$ and high in available potash. Other agronomical operations were carried out as per recommendation. The observation on Plant height, Number of leaves pant ${ }^{-1}$, Stem girth, Cob length, Cob girth, Cob weight plant $^{-1}$, Number of grain row cob ${ }^{-1}$, Nimber of grains $\mathrm{cob}^{-1}$, Fresh weight of grain $\mathrm{cob}^{-1}$, Green cob yield, Green fodder yield were recorded at the time of harvest of crop. Protein content of cob and fodder was calculated by multiplying the nitrogen content with a factor 6.25 as proposed by Tsen and Martin (1971). It was expressed in terms of protein (\%) content.

\section{Results and Discussion}

\subsection{Effect of spacing}

The results revealed that, Growth characters like plant height $(219.61 \mathrm{~cm})$ was recorded significantly higher with spacing $60 \times 20 \mathrm{~cm}^{2}$. The increased plant height in narrow plant spacing might be due to thick plant stand. While $60 \times 30 \mathrm{~cm}^{2}$ was recorded significantly the highest number of leaves plant ${ }^{-1}$ (14.19) and stem girth $(2.12 \mathrm{~cm})$. The stem girth is reduced as compared to wider plant spacing. In wider plant spacing there is abundance of available resources and hence the plants were healthier than thick plant stands. In narrow spacing there was more competition for available resources and hence plants were tall but weaker than wider plant spacing. Almost similar results were observed by Sharma and Gupta (1968) (Table 1).

\begin{tabular}{|c|c|c|c|c|c|c|c|}
\hline \multirow[t]{2}{*}{ Treatment } & \multirow{2}{*}{$\begin{array}{l}\text { Plant } \\
\text { height } \\
(\mathrm{cm})\end{array}$} & \multirow{2}{*}{$\begin{array}{c}\text { Leaves } \\
\text { pant }^{-1} \\
\text { (no.) }\end{array}$} & \multirow[t]{2}{*}{$\begin{array}{l}\text { Stem } \\
\text { girth }(\mathrm{cm})\end{array}$} & \multicolumn{2}{|c|}{$\begin{array}{l}\text { Cob length } \\
(\mathrm{cm})\end{array}$} & \multicolumn{2}{|c|}{$\begin{array}{l}\text { Cob girth } \\
(\mathrm{cm})\end{array}$} \\
\hline & & & & $\begin{array}{l}\text { With } \\
\text { husk }\end{array}$ & $\begin{array}{c}\text { Without } \\
\text { husk }\end{array}$ & $\begin{array}{l}\text { With } \\
\text { husk }\end{array}$ & $\begin{array}{c}\text { Without } \\
\text { Husk }\end{array}$ \\
\hline \multicolumn{8}{|l|}{ Spacing (S) } \\
\hline $\mathrm{S}_{1}: 45 \times 30 \mathrm{~cm}^{2}$ & 211.39 & 13.22 & 2.07 & 25.51 & 17.17 & 14.10 & 9.99 \\
\hline $\mathrm{S}_{2}: 60 \times 20 \mathrm{~cm}^{2}$ & 219.61 & 11.93 & 2.03 & 24.05 & 16.90 & 13.16 & 10.03 \\
\hline $\mathrm{S}_{3}: 60 \times 30 \mathrm{~cm}^{2}$ & 188.28 & 14.19 & 2.12 & 27.18 & 18.11 & 14.94 & 10.67 \\
\hline SEm \pm & 2.61 & 0.31 & 0.01 & 0.46 & 0.13 & 0.17 & 0.15 \\
\hline $\operatorname{CD}(p=0.05)$ & 7.80 & 0.89 & 0.02 & 1.34 & 0.37 & 0.49 & 0.43 \\
\hline \multicolumn{8}{|l|}{ Nutrient management $(\mathrm{N})$} \\
\hline $\mathrm{N}_{1}: 100 \%$ RDF $\left(120: 60: 00 \mathrm{NPK} \mathrm{kg} \mathrm{ha}^{-1}\right)$ & 216.72 & 13.37 & 2.11 & 26.64 & 17.99 & 14.81 & 10.64 \\
\hline $\mathrm{N}_{2}: 75 \% \mathrm{RDF}+25 \%$ RDN through Bio-compost & 204.22 & 13.14 & 2.08 & 25.20 & 17.76 & 14.07 & 10.12 \\
\hline $\mathrm{N}_{3}: 50 \%$ RDF+50\% RDN through Bio-compost & 198.33 & 12.83 & 2.04 & 24.92 & 16.96 & 13.30 & 9.85 \\
\hline SEm \pm & 3.06 & 0.31 & 0.01 & 0.46 & 0.13 & 0.17 & 0.15 \\
\hline $\mathrm{CD}(p=0.05)$ & 8.80 & 0.92 & 0.02 & 1.34 & 0.37 & 0.49 & 0.43 \\
\hline \multicolumn{8}{|l|}{ Bio-fertilizers (B) } \\
\hline $\mathrm{B}_{0}:$ No Bio-fertilizers & 201.96 & 12.89 & 2.05 & 24.80 & 17.07 & 13.61 & 9.91 \\
\hline $\begin{array}{l}\mathrm{B}_{1} \text { : Azotobactor+PSB+KMB (10 ml each kg-1 } \\
\text { seed) }\end{array}$ & 210.89 & 13.34 & 2.10 & 26.37 & 18.07 & 14.53 & 10.53 \\
\hline SEm \pm & 2.50 & 0.25 & 0.01 & 0.38 & 0.10 & 0.14 & 0.12 \\
\hline $\mathrm{CD}(p=0.05)$ & 7.19 & 0.76 & 0.01 & 1.09 & 0.30 & 0.41 & 0.35 \\
\hline
\end{tabular}

In case of yield attributes viz. cob length plant ${ }^{-1}$ with $(27.18$ $\mathrm{cm}$ ) and without husk (18.19 cm), cob girth plant ${ }^{-1}$ with (14.94 $\mathrm{cm}$ ) and without husk $(10.96 \mathrm{~cm})$, cob weight plant ${ }^{-1}$ with husk (202.22 g) and without husk (146.22 g), number of grains row $^{-1}$ of cob (38.94), number of grains $\operatorname{cob}^{-1}$ (459.78), fresh weight of grain $\mathrm{cob}^{-1}(122.28 \mathrm{~g})$ was recorded significantly higher in spacing $60 \times 30 \mathrm{~cm}^{2}$. While, green cob (91.93 q ha-1) and fodder yield (318.65 q ha ${ }^{-1}$ ) was recorded significantly 
higher in spacing $60 \times 20 \mathrm{~cm}^{2}$. The data showed that the cob length decreased as the plant population increased. These results indicate that there is a positive relationship between plant spacing and cob length of maize, probably due to variable plant competition. A wider spacing of $60 \times 30 \mathrm{~cm}^{2} \mathrm{can}$ significantly increase almost all the growth and yield attributes in sweet corn but could not compensate yield obtained in narrower spacing (Thakur et al., 1997). Under high density, more numbers of plants unit ${ }^{-1}$ area was responsible for higher yield. higher plant population utilized the production resources more efficiently towards plant development. The lowest being recorded with the wider spacing. An increase in plant density there was increase in green fodder yield in sweet corn, Hence higher plant population $60 \times 20 \mathrm{~cm}^{2}\left(\mathrm{~S}_{2}\right)$ increased the cob yield by $10.7 \%$ while green fodder yield by $13.6 \%$ over $\mathrm{S}_{1}$ and $\mathrm{S}_{3}$ These findings are in agreement with those of Thakur et al. (1998), Raja (2001), et al. (2006).

Significantly higher protein content in cob (6.97\%) and fodder $(2.92 \%)$ was recorded in spacing $60 \times 30 \mathrm{~cm}^{2}\left(\mathrm{~S}_{3}\right)$. The treatment difference due to various spacing on total sugar content was found non significant.

\subsection{Effect of nutrient management}

Application of $100 \%$ RDF (120:60:00 NPK kg ha-1) recorded the significantly highest plant height $(216.72 \mathrm{~cm})$, number of leaves per plant (13.37) and stem girth $(2.11 \mathrm{~cm})$, cob length per plant with $(26.64 \mathrm{~cm})$ and without husk $(17.99 \mathrm{~cm})$, cob girth per plant with $(14.81 \mathrm{~cm})$ and without husk (10.64 $\mathrm{cm})$, cob weight plant ${ }^{-1}$ with husk (200.50 g) and without husk (154.50 g), number of grains row $^{-1}$ of cob (38.50), number of grains $\mathrm{cob}^{-1}$ (479), fresh weight of grain $\mathrm{cob}^{-1}$ (118.11 g), green cob (90.13 q ha-1) and fodder yield (311.74 $\left.\mathrm{q} \mathrm{ha} \mathrm{h}^{-1}\right)$. The improvement in growth and yield attributes with the application of $100 \%$ RDF might have resulted in better and timely availability of $\mathrm{N}$ and $\mathrm{P}$ for their utilization by plant as judged from nitrogen and phosphorous content of cob and fodder. Nitrogen is considered to be a vitally important plant nutrient. It is an integral part of chlorophyll which is the primary absorber of light energy needed for photosynthesis. Besides these, it is also a constituent of certain organic compounds of physiological importance. Further, phosphorous fertilization also improves the metabolic and physiological processes and thus known as "energy currency" which is subsequently used for vegetative and reproductive growth through phosphorylation. In addition to vital metabolic role, $\mathrm{P}$ is an important structural component of nucleic acid, phytein, phospholipids and enzymes. An adequate supply of phosphorous early in the life cycle of plant is important in laying down the primordia of its reproductive part. The present findings are in close confirmation with those of Raja (2001) on sweet corn, Pathak et al. (2002) on winter maize and Kar et al. (2006) on sweet corn. The significant improvement in overall growth resulted in higher photosynthetic activity has eventually gave higher yield. (Table 2).

Application of $100 \%$ RDF (120:60:00 NPK kg ha-1) recorded the significantly highest protein content in cob (6.91\%) and fodder (2.95\%). Data revealed that nutrient management had non significant effect with respect to total sugar content in grain.

\subsection{Effect of biofertilizers}

Application of Azotobacter+PSB+KMB biofertilizer recorded the significantly highest plant height $(210.89 \mathrm{~cm})$, number of leaves per plant $(13.34)$ and stem girth $(2.10 \mathrm{~cm})$, cob length per plant with $(26.37 \mathrm{~cm})$ and without husk $(18.07 \mathrm{~cm})$, cob girth per plant with $(14.53 \mathrm{~cm})$ and without husk $(10.53 \mathrm{~cm})$, protein content in cob (6.85\%) and fodder (2.85\%), Biofertilizer application increased the growth characters by virtue of fixing atmospheric nitrogen, solubulizing and mobilizing nutrients and it secretes growth promoting substances (Table 1).

The significantly higher cob weight with and without husk per plant (201.51 g and $145.07 \mathrm{~g}$ ) were found with bio fertilizers i.e. Azotobacter+PSB+KMB $\left(B_{1}\right)$. Whereas, the lowest cob weight with and without husk per plant (187.11 $\mathrm{g}$ and $125.07 \mathrm{~g}$ ) were found under no bio fertilizers $\left(\mathrm{B}_{0}\right)$. The higher numbers of grains per row of cob (37.66) were found with biofertilizers i.e. Azotobacter+PSB+KMB $\left(B_{1}\right)$. Whereas, significantly lowest number of grains per row of cob (35.77) were found under no biofertilizers $\left(B_{0}\right)$. The higher numbers of grains per cob (458.88) were found with biofertilizers i.e. Azotobacter+PSB+KMB $\left(B_{1}\right)$. Whereas, the lowest numbers of grains cob $^{-1}$ (389.40) were found under no biofertilizers $\left(B_{0}\right)$. The higher fresh weight of grain $\operatorname{cob}^{-1}(116.11 \mathrm{~g})$ found with biofertilizers i.e. Azotobacter+PSB+KMB $\left(B_{1}\right)$. However, the lowest fresh weight of grain $\operatorname{cob}^{-1}$ (101.51 g) was found under no biofertilizers $\left(B_{0}\right)$. Significantly higher green cob yield $\left(86.64 \mathrm{q} \mathrm{ha}^{-1}\right)$ were found with biofertilizers i.e. Azotobacter+ $\mathrm{PSB}+\mathrm{KMB}\left(\mathrm{B}_{1}\right)$. However, the lowest green cob yield $(77.44 \mathrm{q}$ $\mathrm{ha}^{-1}$ ) was found under no biofertilizers $\left(\mathrm{B}_{0}\right)$. Significantly higher green fodder yield ( $299.68 \mathrm{q} \mathrm{ha}^{-1}$ ) was found with biofertilizers i.e. Azotobacter+PSB+KMB $\left(B_{1}\right)$ over no bio fertilizers $\left(B_{0}\right)$ application (270.96 q ha-1). This could be due to higher nutrient, availability, and higher uptake of nutrients (Table 2).

The significantly higher protein content in cob (6.85\%) and fodder $(2.85 \%)$ found with application of biofertilizers i.e. Azotobacter+PSB+KMB $\left(B_{1}\right)$. The data regarding total sugar content in grain as presented that the different biofertilizers had non significant effect on it.

\subsection{Interaction effect}

Combined effect among spacing, nutrient management and biofertilizers did not reach to the level of significance for growth, yield attributes, cob and fodder yield, protein content and total sugar content. 


\begin{tabular}{|c|c|c|c|c|c|c|c|c|c|c|}
\hline \multirow[t]{2}{*}{ Treatments } & \multicolumn{2}{|c|}{$\begin{array}{l}\text { Cob weight } \\
\text { plant }^{-1} \\
\text { (g) }\end{array}$} & \multirow{2}{*}{$\begin{array}{l}\text { Grain } \\
\text { row } \\
\text { cob }^{-1} \\
\text { (no.) }\end{array}$} & \multirow[t]{2}{*}{$\begin{array}{l}\text { Grains } \\
\text { cob }^{-1} \\
\text { (no.) }\end{array}$} & \multirow{2}{*}{$\begin{array}{l}\text { Fresh } \\
\text { weight } \\
\text { of grain } \\
\text { cob }^{-1} \\
\text { (g) }\end{array}$} & \multirow{2}{*}{$\begin{array}{l}\text { Green } \\
\text { cob } \\
\text { yield } \\
\left(q \text { ha }^{-1}\right)\end{array}$} & \multirow{2}{*}{$\begin{array}{l}\text { Green } \\
\text { fodder } \\
\text { yield } \\
\left(\mathrm{q} \mathrm{ha} \mathrm{ha}^{-1}\right)\end{array}$} & \multicolumn{2}{|c|}{$\begin{array}{l}\text { Protein con- } \\
\text { tent } \\
(\%) \\
\end{array}$} & \multirow{2}{*}{$\begin{array}{c}\text { Total } \\
\text { sugar } \\
\text { content } \\
(\%)\end{array}$} \\
\hline & $\begin{array}{l}\text { With } \\
\text { husk }\end{array}$ & $\begin{array}{l}\text { Without } \\
\text { husk }\end{array}$ & & & & & & Cob & Fodder & \\
\hline \multicolumn{11}{|l|}{ Spacing (S) } \\
\hline $\mathrm{S}_{1}: 45 \times 30 \mathrm{~cm}^{2}$ & 184.72 & 135.83 & 36.43 & 408.89 & 110.55 & 83.68 & 285.62 & 6.78 & 2.73 & 10.39 \\
\hline $\mathrm{S}_{2}: 60 \times 20 \mathrm{~cm}^{2}$ & 174.39 & 123.16 & 34.78 & 403.75 & 93.61 & 91.93 & 318.65 & 6.56 & 2.59 & 10.02 \\
\hline $\mathrm{S}_{3}: 60 \times 30 \mathrm{~cm}^{2}$ & 202.22 & 146.22 & 38.94 & 459.78 & 122.28 & 70.51 & 251.68 & 6.97 & 2.92 & 11.00 \\
\hline SEm \pm & 5.61 & 3.69 & 0.68 & 11.89 & 3.06 & 2.14 & 5.42 & 0.06 & 0.05 & 0.10 \\
\hline $\mathrm{CD}(p=0.05)$ & 16.13 & 10.61 & 1.96 & 34.21 & 8.80 & 6.15 & 15.60 & 0.19 & 0.17 & NS \\
\hline \multicolumn{11}{|l|}{ Nutrient management $(\mathrm{N})$} \\
\hline $\begin{array}{l}\mathrm{N}_{1}: 100 \% \text { RDF }(120: 60: 00 \\
\text { NPK kg ha-1) }\end{array}$ & 200.50 & 154.50 & 38.50 & 479.00 & 118.11 & 90.13 & 311.74 & 6.91 & 2.95 & 10.26 \\
\hline $\begin{array}{l}\mathrm{N}_{2}: 75 \% \text { RDF+25\% RDN } \\
\text { through Bio-compost }\end{array}$ & 181.67 & 138.27 & 36.00 & 409.05 & 109.44 & 81.74 & 285.79 & 6.71 & 2.69 & 10.48 \\
\hline $\begin{array}{l}\mathrm{N}_{3}: 50 \% \text { RDF+50\% RDN } \\
\text { through Bio-compost }\end{array}$ & 179.17 & 112.44 & 35.67 & 384.37 & 98.88 & 74.25 & 258.42 & 6.69 & 2.59 & 10.76 \\
\hline SEm \pm & 5.61 & 3.69 & 0.68 & 11.89 & 3.06 & 2.14 & 5.42 & 0.06 & 0.05 & 0.10 \\
\hline $\mathrm{CD}(p=0.05)$ & 16.13 & 10.61 & 1.96 & 34.21 & 8.80 & 6.15 & 15.60 & 0.19 & 0.17 & NS \\
\hline \multicolumn{11}{|l|}{ Bio-fertilizers (B) } \\
\hline $\mathrm{B}_{0}$ : No Bio-fertilizers & 187.11 & 125.07 & 35.77 & 389.40 & 101.51 & 77.44 & 270.96 & 6.69 & 2.64 & 10.22 \\
\hline $\begin{array}{l}\mathrm{B}_{1}: \text { Azotobactor }+\mathrm{PSB}+ \\
\mathrm{KMB}\left(10 \mathrm{ml} \text { each } \mathrm{kg}^{-1}\right. \\
\text { seed })\end{array}$ & 201.51 & 145.07 & 37.66 & 458.88 & 116.11 & 86.64 & 299.68 & 6.85 & 2.85 & 10.71 \\
\hline SEm \pm & 2.50 & 3.01 & 0.55 & 9.71 & 2.50 & 1.75 & 4.43 & 0.05 & 0.04 & 0.08 \\
\hline $\mathrm{CD}(p=0.05)$ & 7.19 & 8.66 & 1.60 & 27.93 & 7.19 & 5.0233 & 12.74 & 0.15 & 0.13 & NS \\
\hline
\end{tabular}

\section{Conclusion}

From the present findings, it could be suggested that rabi sweet corn (var. Sugar-75) crop sown at $60 \times 20 \mathrm{~cm}^{2}$ spacing and application of 100\% RDF (120:60:00 NPK kg ha-1). It is also seen that biofertilizers i. e. Azotobacter+PSB+KMB (10 ml each $\mathrm{kg}^{-1}$ seed) seems to be beneficial on clayey soil under south Gujarat condition.

\section{References}

Kar, P.P., Baric, K.C., Mahapatra, P.K., Garnayak, L.M., Rath, B.S., Basta, D.K., Khanda, C.M., 2006. Effect of planting geometry and nitrogen on yield, economics and nitrogen uptake of sweet corn. Indian journal of Agronomy, 51(1), 43-45.

Pathak, S.K., Singh, S.B., Singh, S.N., 2002. Effect of integrated nutrient management on growth, yield and economic in maize (Zea mays L.) - wheat (Triticum aestivum) cropping system. Indian Journal of Agronomy 47 (3), 325-332.
Raja, V., 2001. Effect of nitrogen and plant population on yield and quality of super sweet corn (Zae mays) Indian Journal of Agricultural Sciences 46(2), 246-249.

Shivankar, S.K., joshi, R.P., Shuvankar, R.S., 2000. Effect of biofertilizers and levels of nitrogen and phosphorus on yield and uptake by wheat under irrigated condition. Journal of Soils \& Crops 10(2), 292-294.

Thakur, D.R., Om-prakash, Kharwara, P.C., Bhalla, S.K., Prakash, O., 1997. Effect of nitrogen and plant spacing on growth, yield and economics of baby corn (Zea mays L.). Indian Journal of Agronomy 42(3), 479-483.

Thakur, D.R., Om-prakash, Kharwara, P.C., Bhall, S.K., Prakash, O., 1998. Effect of nitrogen and plant spacing on yield, nitrogen uptake and economics in baby corn (Zea mays L.) Indian Journal of Agronomy 43(4), 668-671.

Tsen, C.C., Martin, E.E., 1971. A note on determining protein contents in various wheat flours and flour stream by kjeldhal and neutron activation methods. Cereal Chemistry 48, 721-726. 